\title{
Correction to: The HIV epidemic in Colombia: spatial and temporal trends analysis
}

\author{
Jhon Freddy Montana', Glenda Roberta Oliveira Naiff Ferreira', Carlos Leonardo Figueiredo Cunha', \\ Ana Angélica Rêgo de Queiroz ${ }^{2}$, Wellington Augusto Andrade Fernandes ${ }^{3}$, Sandra Helena Isse Polaro', \\ Lucia Hisako Takase Gonçalves', Danielle Costa Carrara Couto ${ }^{4}$, Elucir Gir ${ }^{5}$, Renata Karina Reis ${ }^{5}$, \\ Wiliam Sorensen ${ }^{6}$ and Eliã Pinheiro Botelho ${ }^{1 *}$
}

\section{Correction to: BMC Public Health 21, 178 (2021) https://doi.org/10.1186/s12889-021-10196-y}

It was highlighted that the original article [1] contained an error in the third paragraph of the Background section. This Correction article shows the incorrect and correct sentence. The original article has been updated.

\section{Incorrect}

The Colombian Caribbean region has the secondhighest prevalence of HIV/AIDS in the world after subSaharan Africa. By the end of 2019, there were 330,000 Colombian PLWHA, 6,900 AIDS-related deaths and 13, 000 new HIV infections recorded in the same year.

\section{Correct}

Colombia is part of the Caribbean region, which has the second-highest prevalence of HIV/AIDS in the world after sub-Saharan Africa. In this region, by the end of 2019, there were 330,000 PLWHA, 6,900 AIDS-related deaths and 13,000 new HIV infections recorded in the same year.

\section{Author details}

${ }^{1}$ Nursing Graduate Program, Federal University of Para, Rua Augusto Correia, 01, Complexo Saúde, Guamá, Belém, Para 66075-110, Brazil. ²Nursing Department of Federal University of Rio Grande do Norte, Centro das Ciências da Saúde, Campus Universitário Lagoa Nova, Natal, Rio Grande do Norte 59078-970, Brazil. ${ }^{3}$ Laboratory of Spatial Analyzes (LAENA), Center for
Amazonina Studies (NAEA), Federal University of Para, Rua Ausgusto Correia, 01, Complexo Engenharia, Guamá, Belém, Para 66075-110, Brazil. ${ }^{4}$ School of Technology in Geoprocessing, Federal University of Pará, Rua Augusto Correia, 01, Complexo Engenharia, Guamá, Belém, Para 66075-110, Brazil. ${ }^{5}$ Graduate Program of Fundamental Nursing. Nursing School of Ribeirao Preto, University of Sao Paulo, Av dos Bandeirantes, 3900. Campus Universitario - Monte Alegre, Ribeirao Preto, Sao Paulo 14040-902, Brazil. ${ }^{6}$ Department of Health \& Kinesiology, University of Texas at Tyler, 3900 University Blvd., Tyler, TX 75799, USA.

Published online: 20 April 2021

\section{Reference}

1. Montana JF, et al. The HIV epidemic in Colombia: spatial and temporal trends analysis. BMC Public Health. 2021;21:178. https://doi.org/10.1186/s12 889-021-10196-y.

The original article can be found online at https://doi.org/10.1186/s12889021-10196-y.

* Correspondence: elipinbt@gmail.com; ebotelho@ufpa.br

${ }^{1}$ Nursing Graduate Program, Federal University of Para, Rua Augusto Correia,

01, Complexo Saúde, Guamá, Belém, Para 66075-110, Brazil

Full list of author information is available at the end of the article

C The Author(s). 2021 Open Access This article is licensed under a Creative Commons Attribution 4.0 International License, which permits use, sharing, adaptation, distribution and reproduction in any medium or format, as long as you give appropriate credit to the original author(s) and the source, provide a link to the Creative Commons licence, and indicate if changes were made. The images or other third party material in this article are included in the article's Creative Commons licence, unless indicated otherwise in a credit line to the material. If material is not included in the article's Creative Commons licence and your intended use is not permitted by statutory regulation or exceeds the permitted use, you will need to obtain permission directly from the copyright holder. To view a copy of this licence, visit http://creativecommons.org/licenses/by/4.0/ The Creative Commons Public Domain Dedication waiver (http://creativecommons.org/publicdomain/zero/1.0/) applies to the data made available in this article, unless otherwise stated in a credit line to the data. 